\title{
Walking on This Earth, Finding Belonging: Ruminations of an Unsettled Settler
}

\author{
Stephanie Bartlett \\ University of Calgary
}

\begin{abstract}
:
In this paper, I contemplate my positionality as a non-Indigenous settler of Scottish, English and German descent. I (re)visit places that have shaped my life-journey and engages in a thoughtful participation between language, land and my positionality as an emerging researcher within an Indigenist paradigm. I consider Regan's (2010) concept of the unsettled settler, defined as nonIndigenous people learning to embrace the struggle to face truths of colonialism and the consequences of the Indian Residential School system. Through photovoice and poetic inquiry, I reflect on my own encounters with the land and more-than-human relatives as a way to disrupt colonial assumptions. Ruminations, pictures and a collection of poems invite an exploration of the curricular implications of land-based teachings and reconciling ways of knowing with the land. By delving into and sharing my own personal experiences on the land, I hope to invite non-Indigenous educators to consider their own positionality and relationship with the land as part of their response to the Truth and Reconciliation (2015) calls to action.
\end{abstract}

Keywords: Blackfoot language; curriculum; Indigenous ways of knowing; land; photovoice; poetic inquiry 


\title{
Marcher sur cette terre, trouver son appartenance : les ruminations d'un colon instable
}

\author{
Résumé : \\ Dans cet article, je contemple ma positionnalité en tant que colon non autochtone d'origine \\ écossaise, anglaise et allemande. Je (re)visite des lieux qui ont façonné mon parcours de vie et \\ m'engage dans une participation réfléchie entre la langue, la terre et ma positionnalité en tant \\ que chercheuse émergente au sein d'un paradigme autochtone. Je considère le concept de \\ Regan (2010) du colon instable, défini comme un peuple non autochtone apprenant à se battre \\ pour affronter les vérités du colonialisme et les conséquences du système des pensionnats \\ indiens. À travers la photographie et l'enquête poétique, je réfléchis à mes propres rencontres \\ avec la terre et des parents plus qu'humains comme moyen de perturber les hypothèses \\ coloniales. Des ruminations, des images et une collection de poèmes invitent à explorer les \\ implications curriculaires des enseignements basés sur la terre et à réconcilier les manières de \\ savoir avec la terre. En explorant et en partageant mes propres expériences personnelles sur la \\ terre, j'espère inviter les éducatrices(teurs) non autochtones à considérer leur propre \\ positionnalité et leur relation avec la terre dans le cadre de leur réponse aux appels à l'action de \\ la Commission de vérité et réconciliation du Canada (2015).
}

Mots clés : la langue des Pieds-Noirs; curriculum; les modes de savoir autochtones; la terre; la voix aux photos; l'enquête poétique 
Being on the land is a highly intellectual practice that is a living interaction between heart, mind, and movement.

(Simpson, 2017, p. 215)

\title{
Who Am I and Where Do I Come From?
}

\begin{abstract}
y name is Stephanie. My ancestry is Scottish, English and German, and I grew up on the un-ceded land of the Qayqayt First Nation, members of the Coast Salish peoples. I am a mother to two children and have been an educator for 21 years. I now live in
\end{abstract} Blackfoot territory where I am guided on a journey by Blackfoot Elder Saa'kokoto, Randy Bottle. I seek to inspire myself and other educators to build relationships with the land and Elders so that we can teach children to care for each other and the Earth.

I am learning to develop a kinship with the land and connect Indigenous ways of knowing, being and doing to education in respectful ways (Donald, 2016; Kelly, 2018; Wilson, 2008). Eve Tuck and Ruben Gaztambide-Fernández (2013) critiqued the field of curriculum studies, pointing out that the field has "played a significant role in the maintenance of settler colonialism" (p. 76). Similarly, Dwayne Donald (2016) has challenged curriculum scholars to move past a reflective response to current events and colonialism towards a complete (re)imagining of what curriculum could look like during these times of reconciliation. Both learning on the land and thinking about positionality and relationships are critical responses to curriculum studies that are urgently needed.

I am keenly aware of my heritage and the assumptions, barriers and misunderstandings that I carry (Regan, 2010; Tuck \& Yang, 2012). I recognize that my connection with land is flawed. No matter how much my identity is shaped by land, I grew up in a position of White privilege on unceded land that belongs to Indigenous peoples (Adams, 2006; Simpson, 2017; Tuck \& Yang, 2012). I do not seek to ignore, erase or appropriate Indigenous knowledges, nor do I seek to make them my own (Tuck \& Gaztambide-Fernández, 2013). Understanding a path towards truth and reconciliation requires engaging in the ongoing work of recognizing the colonial project in its past and present forms (Battiste, 2013; Simpson, 2017; A. Smith, 2005; L. Smith, 2012). This includes acknowledging my role in the colonial project as a result of the privilege of being born a settler.

The conscious awakening that I have about my own colonial past is as much a part of me as my intricate connections to the land where I grew up. Reflecting upon childhood memories and placing them alongside current experiences on this Indigenous learning journey guided by a Blackfoot mentor opens up further reflection about the knowledge that I carry in my bones. This knowledge that I carry from my childhood calls forth my relationship to land as a settler.

I have always loved nature, particularly dense forests, rocky beaches, oceans and lakes. Growing up, I spent more hours than I can count lying on my back staring at the trees, the clouds and the mountains. This genuine appreciation equates to Sandra Styre's (2019) definition of land with a lower case "I", which refers to "physical geographic space" (p. 27). That is, I enjoyed visiting 
places of personal significance and felt both peaceful and energized, but I didn't understand or couldn't articulate what it meant to be in relationship with those places. On the other hand, Land with a capital " $L$ " is "both space (abstract) and place/land (concrete). . . Land is spiritual, emotional, and relational; Land is experiential, remembered, and storied; Land is consciousness-Land is sentient" (Styres, 2019, p. 27, italics in original). I visit with Indigenous perspectives to better understand our relationships - with each other, the Land, and our more-than-human relatives-as important aspects of truth and reconciliation. I can't ever fully understand the sacredness of Indigenous peoples' relationships to the Land. I am, though, trying to practice respect, responsibility, and reciprocity, as I nurture a relationship with the Land $^{1}$ (Wall Kimmerer, 2013; Wilson, 2008).

\section{Where Am I Going?}

In my work, I turn to an Indigenist paradigm to understand how I can immerse myself respectfully in Indigenous research (Martin \& Mirraboopa, 2003; Tanaka, 2016; Wilson, 2007). Cree scholar Shawn Wilson (2007) describes an Indigenist research paradigm as a deeply personal call to engage in Indigenous research, regardless of the cultural background of the researcher. NonIndigenous scholar Michele Tanaka's (2016) research and teaching is guided by Elders and influenced by relationships with herself, with others, and with the Earth (p. 12). I feel a sense of tentative affirmation to discover that there is a space for non-Indigenous researchers who find themselves, as I do, between two worldviews: Western and Indigenous ways of knowing, being and doing. Yet, engaging in Indigenist methodologies requires that I do the ongoing hard work of understanding both perspectives, as well as the ongoing impact of colonialism (Coulthard, 2014; Kovach, 2015; Simpson, 2017; L. Smith, 2012; Tuck \& Yang, 2012).

This exploratory paper seeks an ethical balance between two worldviews (Little Bear, 2000) using photovoice (Cook \& Buck, 2010; Higgins, 2014; Wang \& Burris, 1997) and poetic inquiry (Leggo, 2019; Prendergast et al., 2009; Sameshima et al., 2017). I see balance as a careful attention to the four "R's" of Indigenous research methodologies, which are respect, responsibility, relationship and reciprocity (Kirkness \& Barnhardt, 1991; Wilson, 2008). Aesthetically, the photographs and the accompanying poetry are aligned in the centre margin to represent my effort to find balance between worldviews.

\section{Walking as an Unsettled Settler}

Director of Research for the Truth and Reconciliation Commission of Canada Paulette Regan (2010) describes an unsettling pedagogy as when one takes "the necessary time to critically reflect upon one's own decolonizing journey in ways that translate into action" (p. 197). She goes on to explain that "the challenge for settlers is to listen attentively, reflectively, and with humility" (p. 211). Although Regan refers to dialogue between Indigenous peoples and settlers, this paper is an attempt to extend the concept of unsettling towards shifting relationships between humans and the Land.

\footnotetext{
${ }^{1}$ Part of the exploratory nature of this paper is to create a conceptual usage of the term Land. I will continue to use land with a lower case "I" except when I am trying to highlight the sentient nature of Land with an upper case "L".
} 
The collection of poetry that appears later in the paper is an active contribution to my unsettling as I move from understanding land as places with meaningful memories, to a relationship with the Land and our more-than-human relatives.

Rooted in a space of "critical hope" (Regan, 2010, p. 22), I look to Indigenous peoples, the Land and more-than-humans to listen and to learn. Robin Wall Kimmerer (2020) acknowledged that the work of reconciling ways of knowing is a struggle. This active struggle to recognize truth seems to be a necessary part of the journey towards a hopeful future. Paulo Freire writes that, "without a minimum of hope, we cannot so much as start the struggle. But without the struggle, hope ... dissipates, loses its bearings and turns into hopelessness. ... Hence the need for a kind of education in hope" (Friere, 1995, p. 8-9). Connecting to my past and present through the Land is hopeful to me. I lean into this struggle.

Reconciling ways of knowing for the future of the Earth asks that Indigenous knowledge systems be valued and understood as vital to environmental stewardship (Wall Kimmerer, 2020). Robin Wall Kimmerer (2020) shared that this is not about environmental management. It is about relational teachings with the Land. Further, Sandra Styres (2019) wrote that "there is a Haida teaching that states 'we do not inherit the land from our ancestors-we borrow it from our children'" (p. 28). This teaching awakens the senses. If we borrow the land from our children, then it is an imperative that we care for it lovingly and carefully.

As I experience learning on the Land with Elder Saa'kokoto, I am becoming more attuned to my own life and my positionality. I realize that these experiences are at once personal and pedagogical. My experiences on the Land are similar to those of children sitting in circle with an Elder. I listen carefully with an open heart and yet, after the lesson, I see two choices: I could reflect on a beautiful experience and let it drift in my memory, or, in the work of unsettling the settler (Regan, 2010), I could ask what I am to do with these teachings. Elder Saa'kokoto shares that he hopes that the wisdom of his lessons and teachings end up at home:

It's what's at the kitchen table that matters. The family is learning from what the kids are learning in school. Students are dealing with colonization every day. But when we take them out on na'a and teach them to appreciate the lessons of na'a and the Blackfoot language and history, we plant the seeds of Indigenous knowledges for the future. We plant the seeds and the students go out and educate the community. The students are the ones who carry this forward. It's the kitchen table where we change attitudes (Saa'kokoto, Kainai Nation, lives in Calgary, Alberta; oral teachings, September 25, 2020).

When children have the opportunities to learn and teach others, we all move forward on the path towards truth and reconciliation. Educators are required to address the Truth and Reconciliation (2015) calls to action. Accordingly, a deep inquiry of self-in-relation to colonial and Indigenous worldviews provides an opening of how educators could begin or further their own journeys so that they can seek learning experiences for their students. Learning to appreciate the land and different stories and teachings should never be a one-time experience that reinforces the colonial project 
(Tuck \& Gaztambide-Fernández, 2013). Instead, working together over time with Elders and knowledge keepers helps to keep knowledge moving forward towards a collective future (Elder Saa'kokoto, oral teachings, c. 2017-2020; Tanaka, 2016; Wall Kimmerer, 2020).

Where possible, I use Blackfoot words that I have learned through experiences on the Land with Elder Saa'kokoto. I am drawn to the verb-based, action-oriented Blackfoot language. African scholar Bagele Chilisa (2012) suggests that using Indigenous language wherever possible as part of an Indigenous research methodology becomes an act of decolonization. Learning words as part of an encounter with Land or a more-than-human relative feels like a small, significant gift of traditional knowledges for me to respect.

I offer the following glossary of Blackfoot words in Figure 1 as a pedagogical invitation. Traditionally, Blackfoot language is an oral language. I have provided a phonetic guide down the centre of the glossary, created with Elder Saa'kokoto as an invitation to practice these words as they appear in the poetry that follows.

\begin{tabular}{|c|c|c|}
\hline Blackfoot Word & Phonetic Pronunciation & English Translation \\
\hline asinai'pii & ah sin a pee & Writing-on-Stone Provincial Park \\
\hline ehsikotoii & eh see koh to yee & white-tailed deer \\
\hline giaiyou & Gee eye you & bear \\
\hline gii'nii & gee knee & rosehips \\
\hline iipootaiks & ee poe tehks & the winged ones \\
\hline$k a k h^{\prime} \sin$ & $k a h k^{\prime} \sin$ & bear berry \\
\hline ko'komikisum & koe koe mo kee suum & Moon \\
\hline ksisktaki & ksisk tah kee & beaver \\
\hline$n a^{\prime} a$ & nah'ah & Mother Earth \\
\hline nitsitapii & knee see ta pee & the real people, including the Blackfoot \\
\hline natoosi & na toe see & Sun \\
\hline okonokii & oh koh noh kee & Saskatoon berries \\
\hline
\end{tabular}

Figure 1. Glossary of Blackfoot terms. Includes phonetic pronunciation and English translation.

As a reciprocal act, I practice these words-roll them over my tongue and squirm at my mispronunciation when it takes many tries to pronounce a word properly. But taking the time and effort to pronounce a word properly matters (Basso, 1997; Kovach, 2015). Slowing down to listen carefully demonstrates the significance of the words that I am learning. Taking the time to practice shows Elder Saa'kokoto that I understand the responsibility that I carry to now refer to these relations by their original names.

\section{Research Methods}

Together, photovoice and poetic inquiry simultaneously connect and juxtapose different perspectives. Photovoice originated as a process where people were invited to take pictures and 
reflect critically about their own photos in relation to a participatory research study (Wang \& Burris, 1997). Though rooted in a Western research tradition, photovoice is compelling here for two reasons. First, Marc Higgins (2014), a scholar who seeks to articulate the space between Indigenous and Western ways of knowing, recognized the impact of photovoice with/in research participants. He conceptualized a "rebraid" of photovoice that draws upon Indigenous research traditions and community values so that it fits within Indigenous cultural contexts (p. 209). Second, photovoice as a pedagogical tool is introspective and empowering (Cook \& Buck, 2010). Deeply pedagogical in its own right, poetry is a nourishing and loving response to my insights (Leggo, 2019; Sameshima et al., 2018). I will walk you, Reader, through a tangled mix of words and photos representing a topography specific to Indigenous and settler land-based experiences. The pictures amplify my words, helping me to articulate how I walk in the world as educator, researcher, human. In so doing, I simultaneously contemplate the pedagogical implications.

\section{Process}

Many of the following poems reflect Elder Saa'kokoto's teachings. I followed Blackfoot ceremonial protocols and asked for his guidance. Elder Saa'kokoto gave his permission for me to share his teachings within the context of this paper. In a series of what Sto'lo scholar Jo Ann Archibald (2008) refers to as informal research chats, I took care to share various drafts of my evolving work, incorporating Elder Saa'kokoto's thoughts and feedback into various drafts and revisions. Even with guidance, I often heard the voice of the unsettled settler within (Regan, 2010) chiding me, reminding me that there are stories about the Land that I can't share as a settler. Then, the voice of my Elder teacher, telling me that I can trust my heart. That it's ok. And that his lessons and stories will help me to understand my own. When speaking about truth and reconciliation, Elder Saa'kokoto reminds people that

what happened generations ago in residential schools is not your fault. But you need to listen to the stories. To learn. Once you know, it is your responsibility to share the knowledge that you have gained. To share with others so that they will know. That is the action. (Saa'kokoto, Kainai Nation, lives in Calgary, Alberta; oral teachings, February 3, 2020).

As part of my process, I began by placing the collection of land-based photographs together, then layered my poetry. Throughout the process, I noticed overarching values such as patience, reciprocity and love from my Land-teachers. I wondered what new possibilities might reveal themselves through this work and what it might mean for children to learn these teachings from the Land. Within each collection of photos, there was often a cycle through the seasons or through time as my learning deepened through (re)visiting a place. The poetic ruminations that follow seek to answer the questions: how might a close examination of land photography teach me new perspectives about who I am in my research and how I came to be here? How might this effort to compose my positionality in relation to the land be relevant for others who seek to do the same? Why might this be relevant for curriculum and teaching? 


\section{Poetic and Photographic Ruminations ${ }^{2}$}

\section{Learning from Niitsitapi}

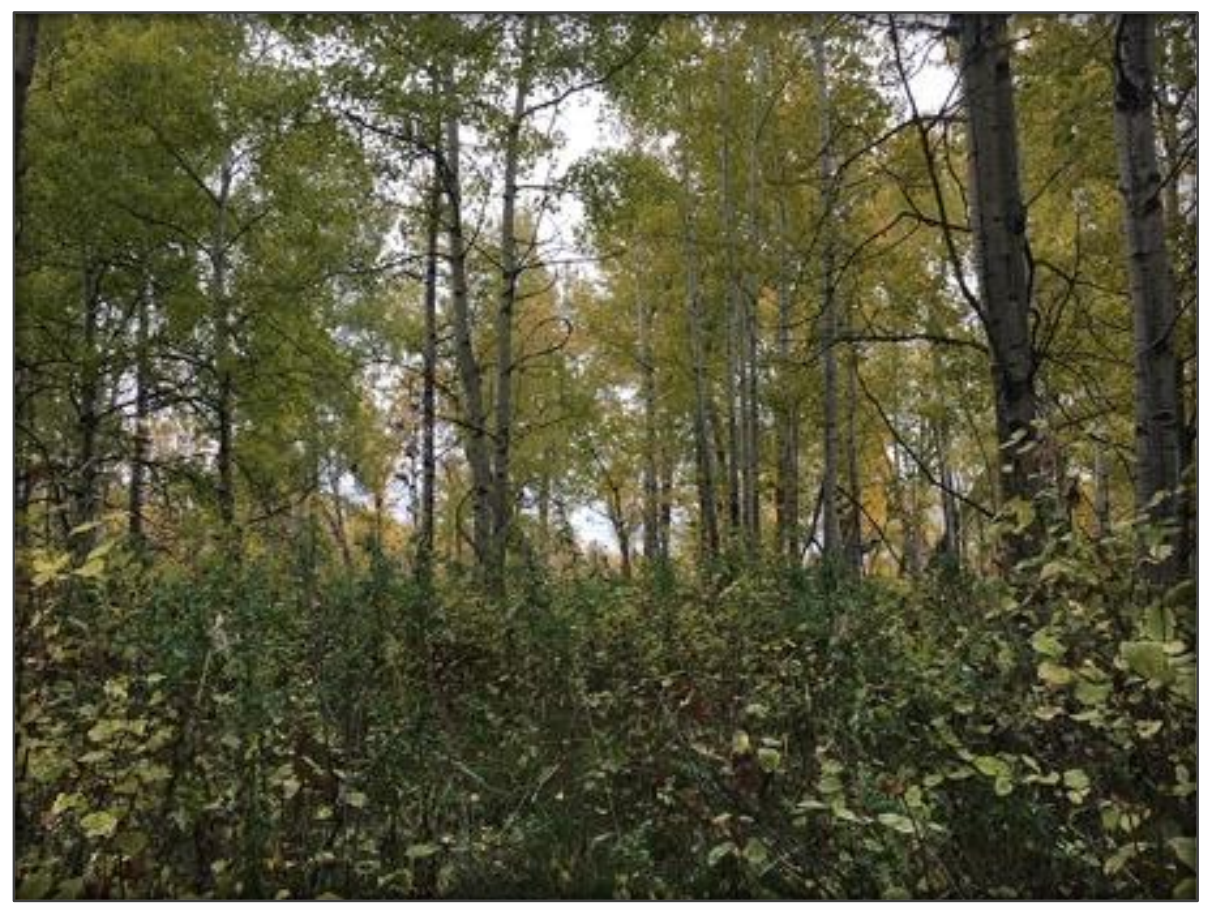

birds

sang louder than my thoughts

intertwining song and wind

$$
\text { natoosi }
$$

cast her light

whimsical movement of shadows

changing direction

ehsikotoii jumped through the grove

ipootaiks flew this way and that

no fear

cacophony of

more-than-human movements

sounds-inter-connected

beckoned me to pay attention

${ }^{2}$ All photos taken by the author. 
I took this in

leaned back gazed

left, right

near, far

trees parted in a new line of sight

forming a shared path extending

as far as I could see

to the left aspen stood tall, close

together sharing

connected root systems

supporting young and old

to the right

spaced yet entangled mix

aspen and poplar

either leaning closer or bending away

Natoosi

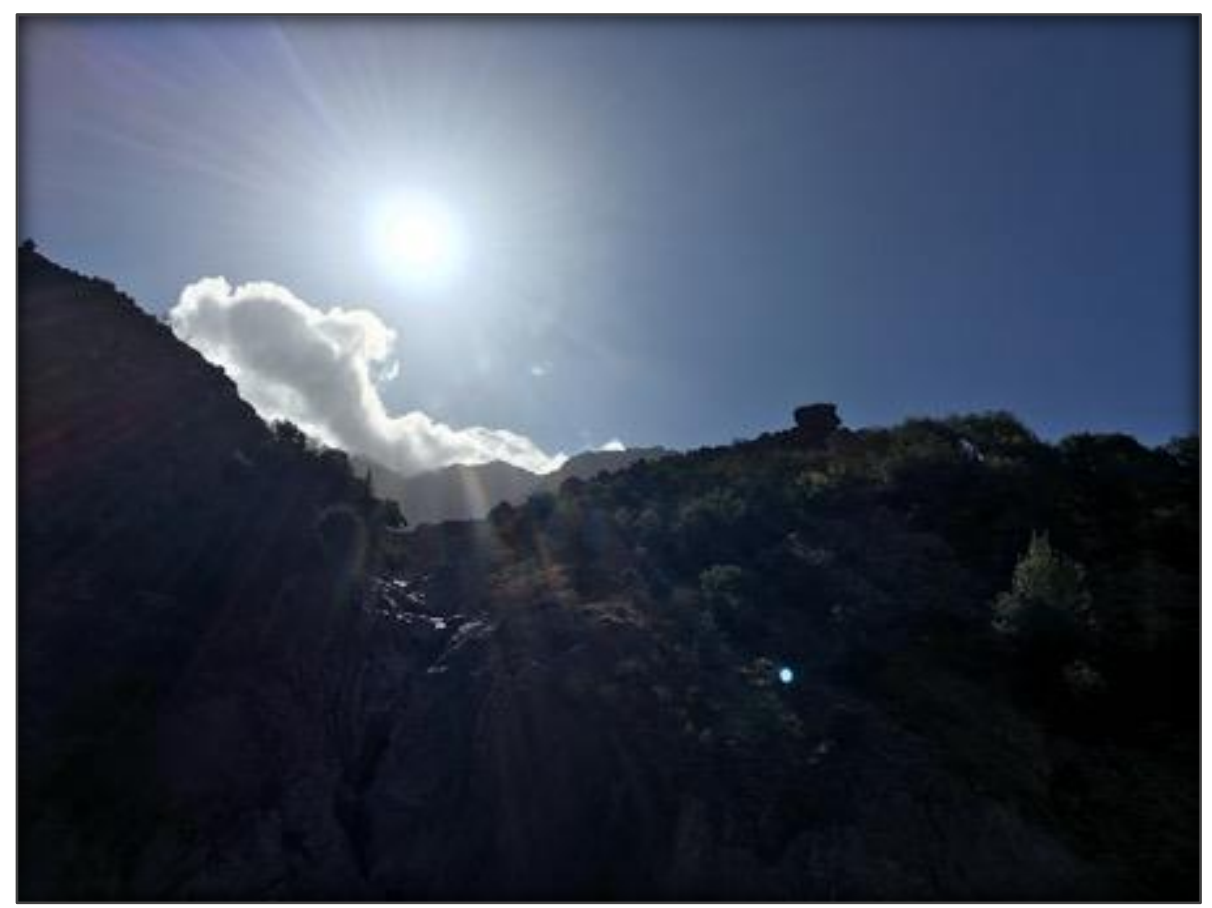




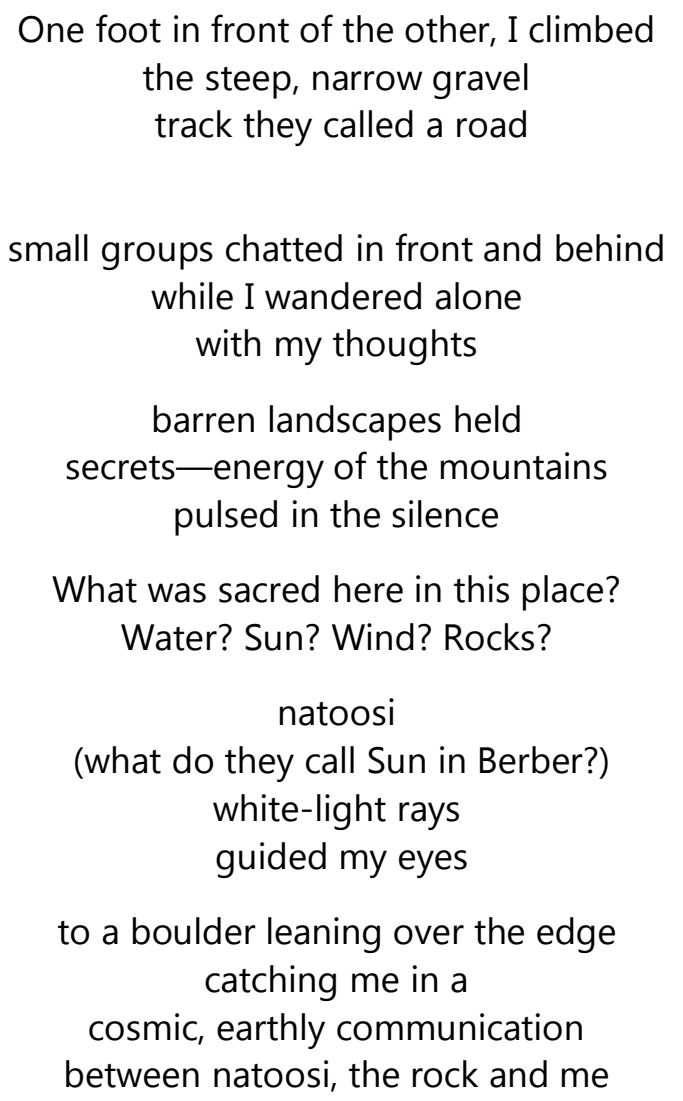




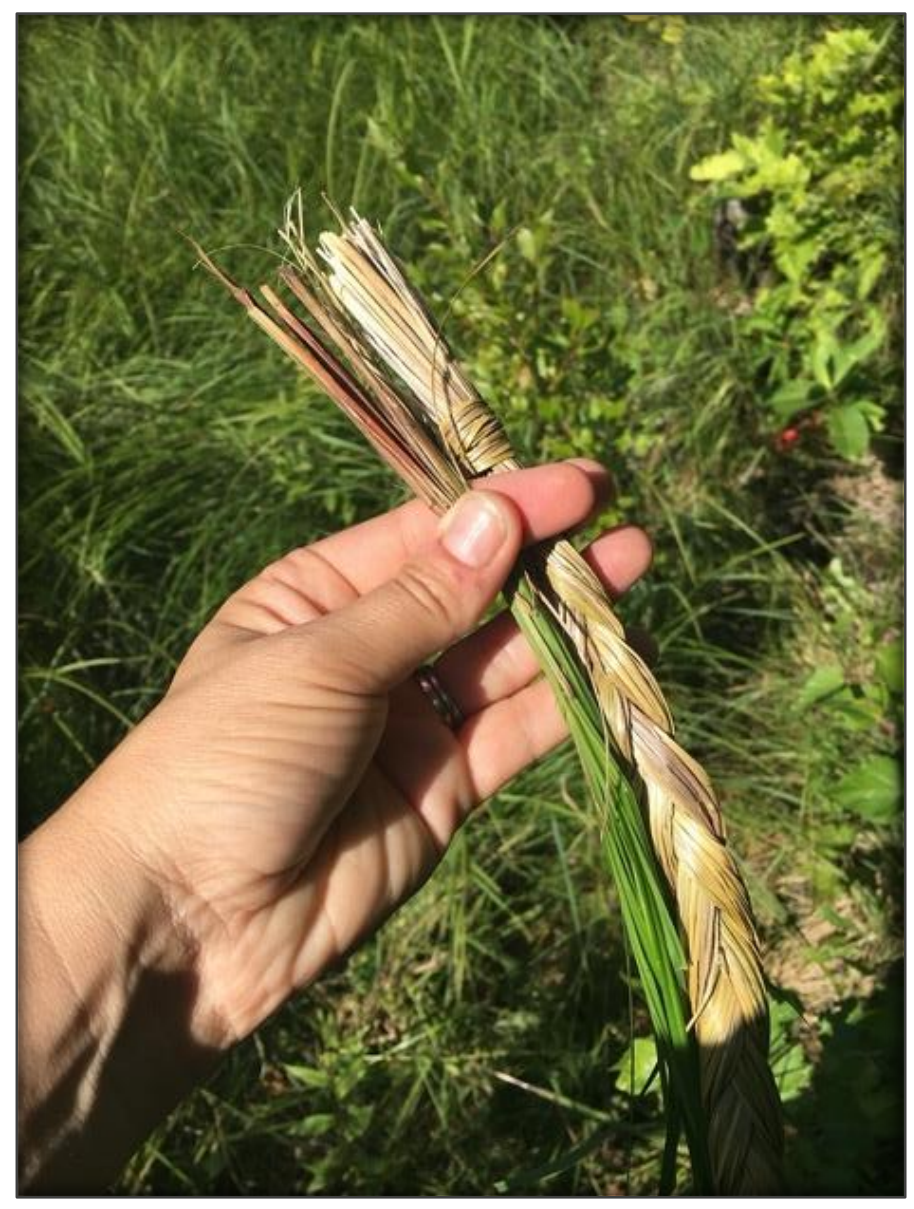

$$
\begin{aligned}
& \text { the strength of a braid } \\
& \text { nudges me to remember } \\
& \text { gifts offered by na'a }
\end{aligned}
$$

I tried searching for sweetgrass

$$
\text { last summer }
$$

but didn't succeed

she wasn't ready to reveal herself

I am learning

some knowledge is not for me equally beckoning elusive protected 


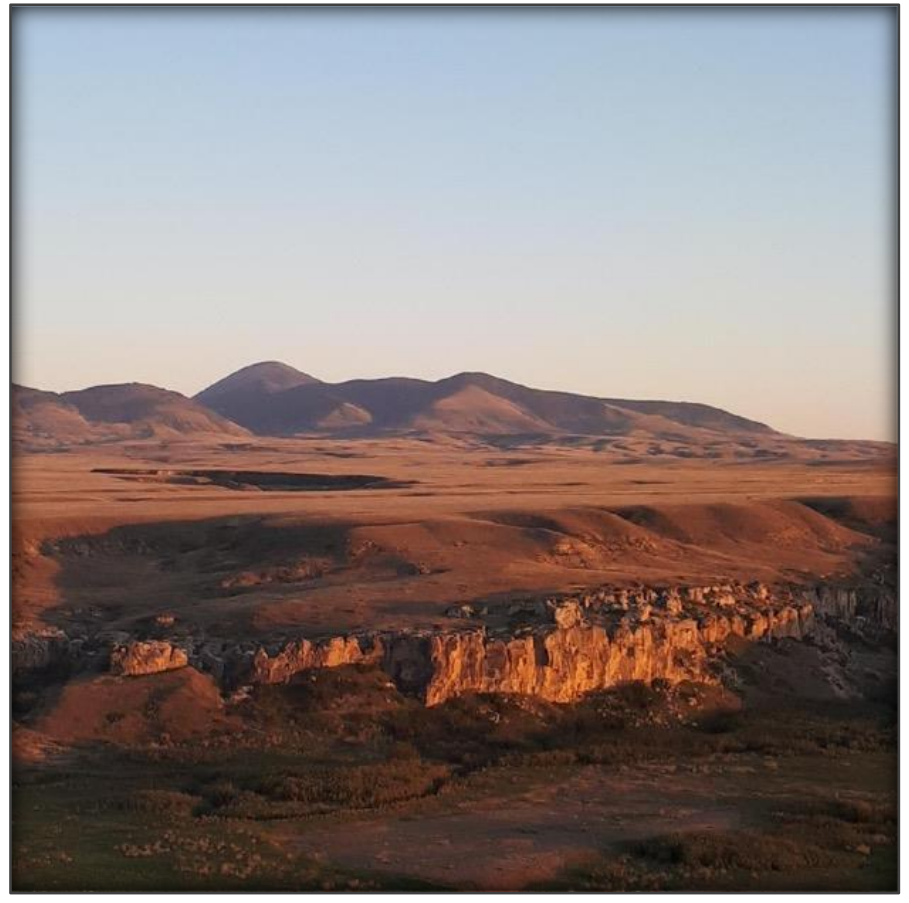

Most people in Alberta know this place

as Writing-on-Stone Provincial Park, but the Blackfoot people have always called it Asinai'pii

when I first went, I knew it as Writing-on-Stone sacred university for the Elders

I also knew that there were spirits that the wind blew, hard

some Blackfoot people do not want to sleep in the river valley while others embrace the whispers of the ancestors in the wind 


\section{Gii’nii}

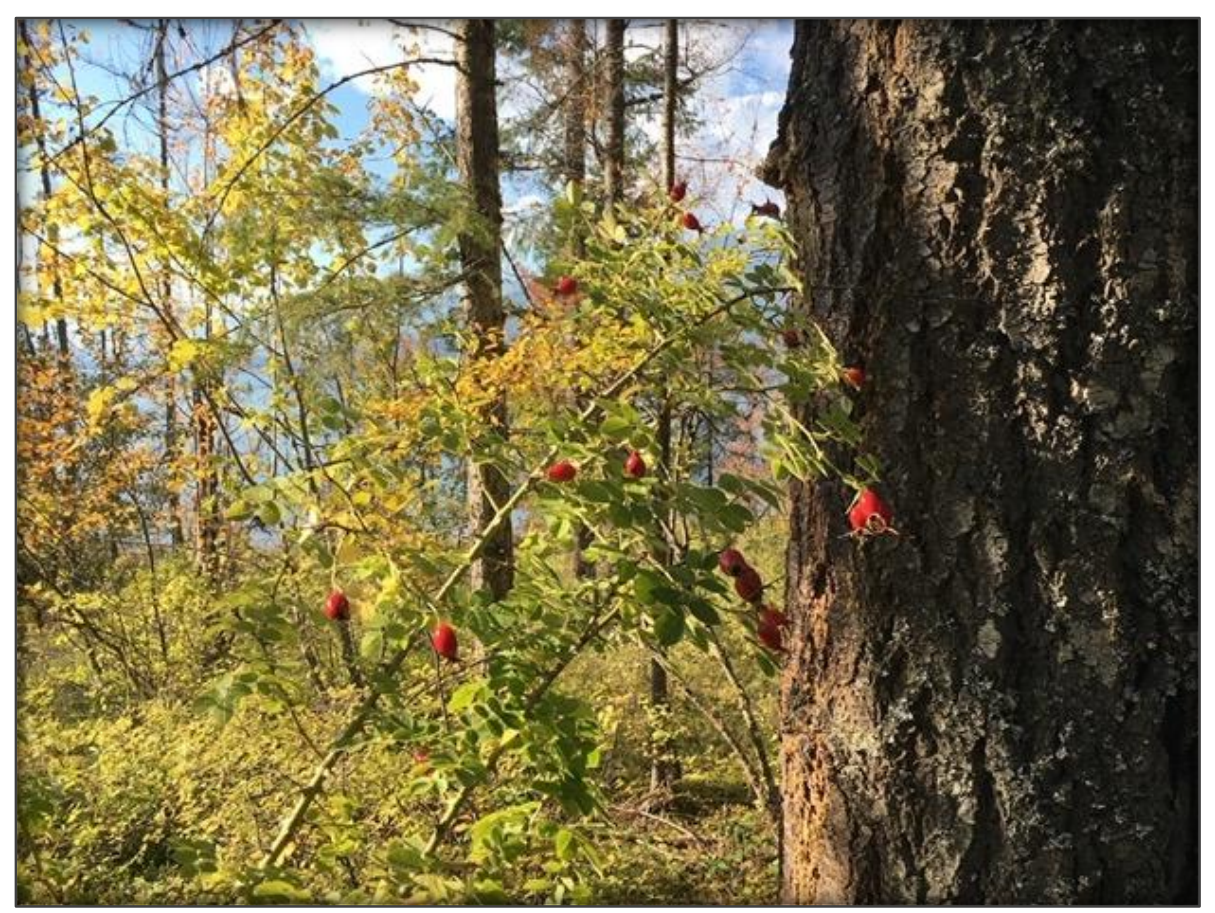

My rose hip lessons began in early summer funny how I paid attention and yet even then, I didn't know that gii'nii had gently decided to teach me

that their vitamin $C$ is the reason why colonizers survived those first winters that the generosity of Indigenous peoples led them to share their knowledge

this told to us tongue in cheek with a wry smile and a short laugh by a Cree colleague sharing plant knowledge with teachers gii'nii and I met again in early fall when I learned that I could make tea reciprocity harvest take just what you need my friend said to me 
humbled by protocols and a growing sense of pride something shifted in my heart before I could catch up and understand

\section{Okonokii}

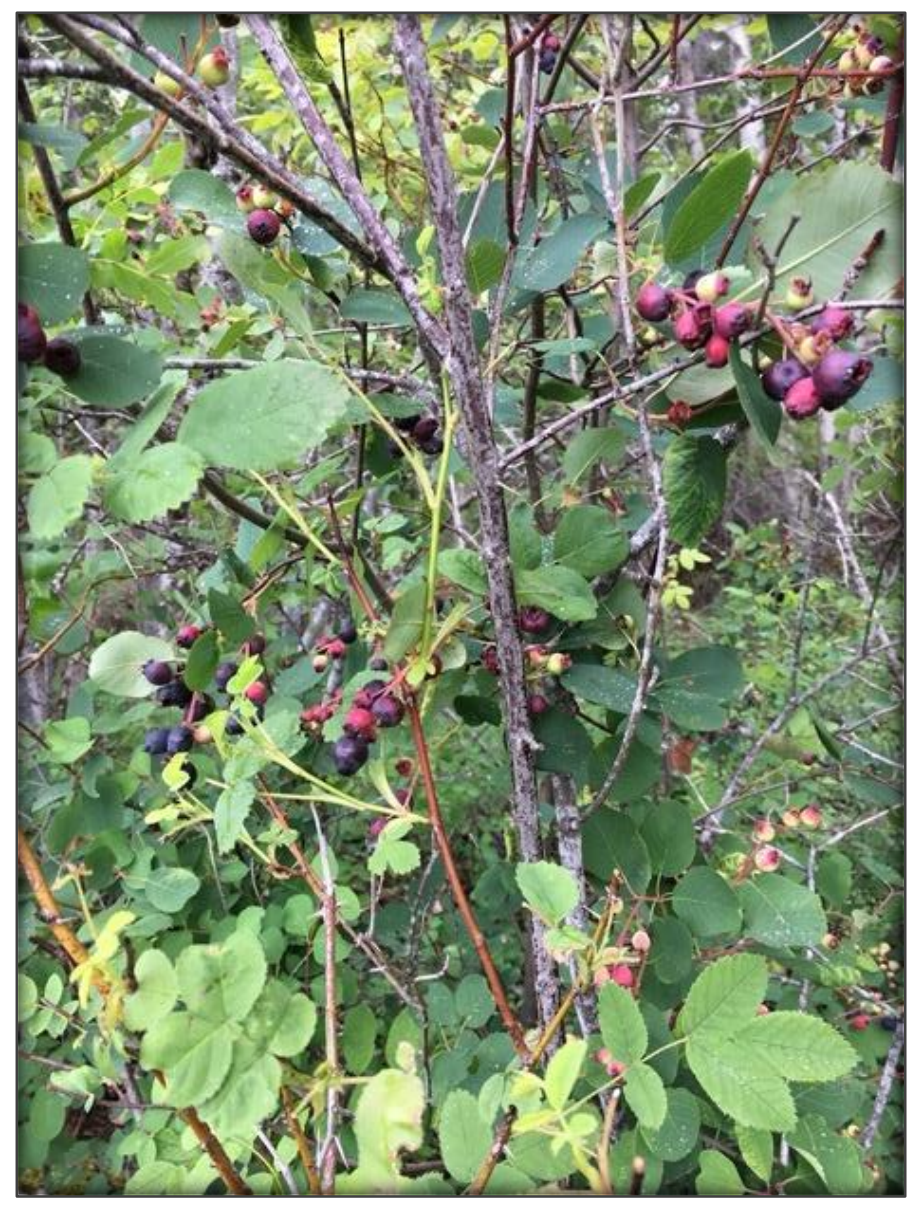

Saskatoon berries don't always grow in abundance, in fact, for most years of my childhood, okonokii shrivelled and dark were best left to iipootaiks, the birds

if I could measure time by okonokii, it would move slowly berries dripping from every bush has happened twice in thirty years 
I haven't seen them like this since I was a kid! exclaimed my uncle as we shared okonokii when I was young

I haven't seen them like this since I was a kid! I shouted in delight to my own children last summer realizing they were the same age as I was the last time they were plentiful

I taught my own children how to care for okonokii taking some to enjoy but leaving enough to share for iipootaiks and giaiyou, the bear

\section{Kakh'sin}

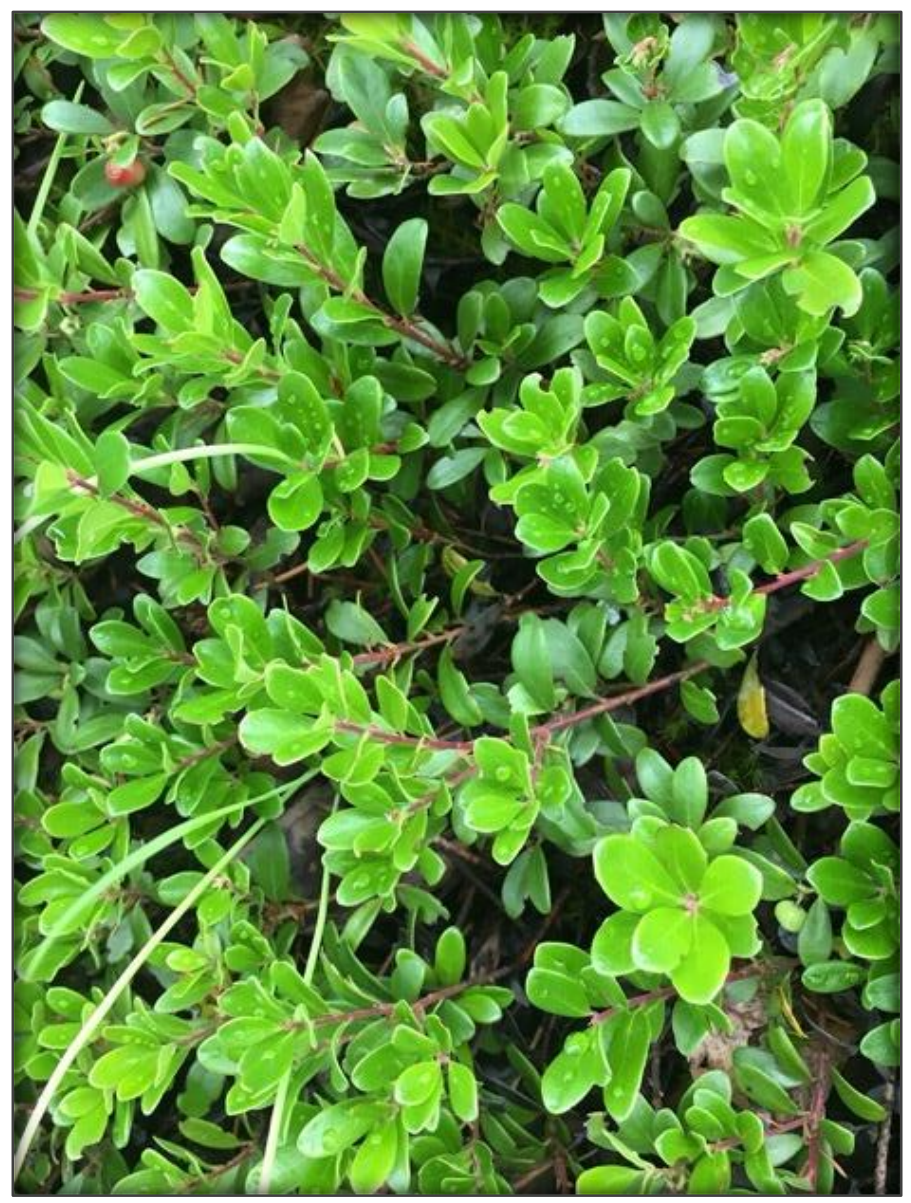


vibrant green leaves, gathered like family embracing my learning, yet still an arm's length away from understanding

\section{lipootaiks}

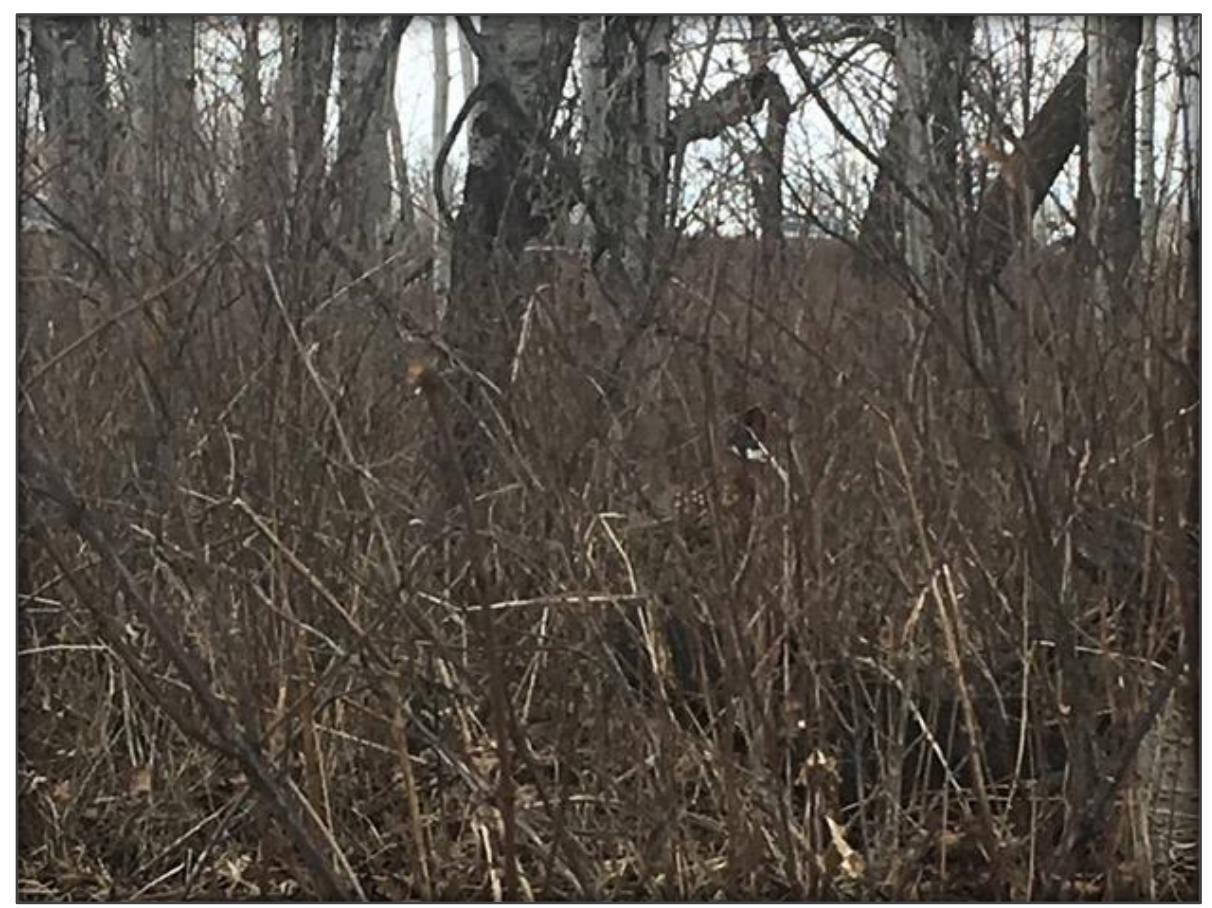

too much time at the computer trying

to write about research paradigms

methodologies and the like

I sat

in the brown grass

amongst aspen trees, let

my mind, spirit attune

I noticed

iipootaiks accepted my presence,

began to call

swooping down and around

to the presence of my more-than-human

relatives

I watched, waited 
two pheasants walked together

feeding in the grass

one camouflaged, the other shone

bright amidst dull foliage moving slowly

in the safety and freedom of the hidden grove

I exhaled, felt

words take shape, smiled and began to write

in the textured silence

I bore witness to more winged ones that day robins, chickadees

ducks, woodpeckers

chirped, pecked

as they ventured close to my place

on the log, offering

advice and support

iipootaiks, the winged ones

taught me to listen 


\section{Ksisktaki}

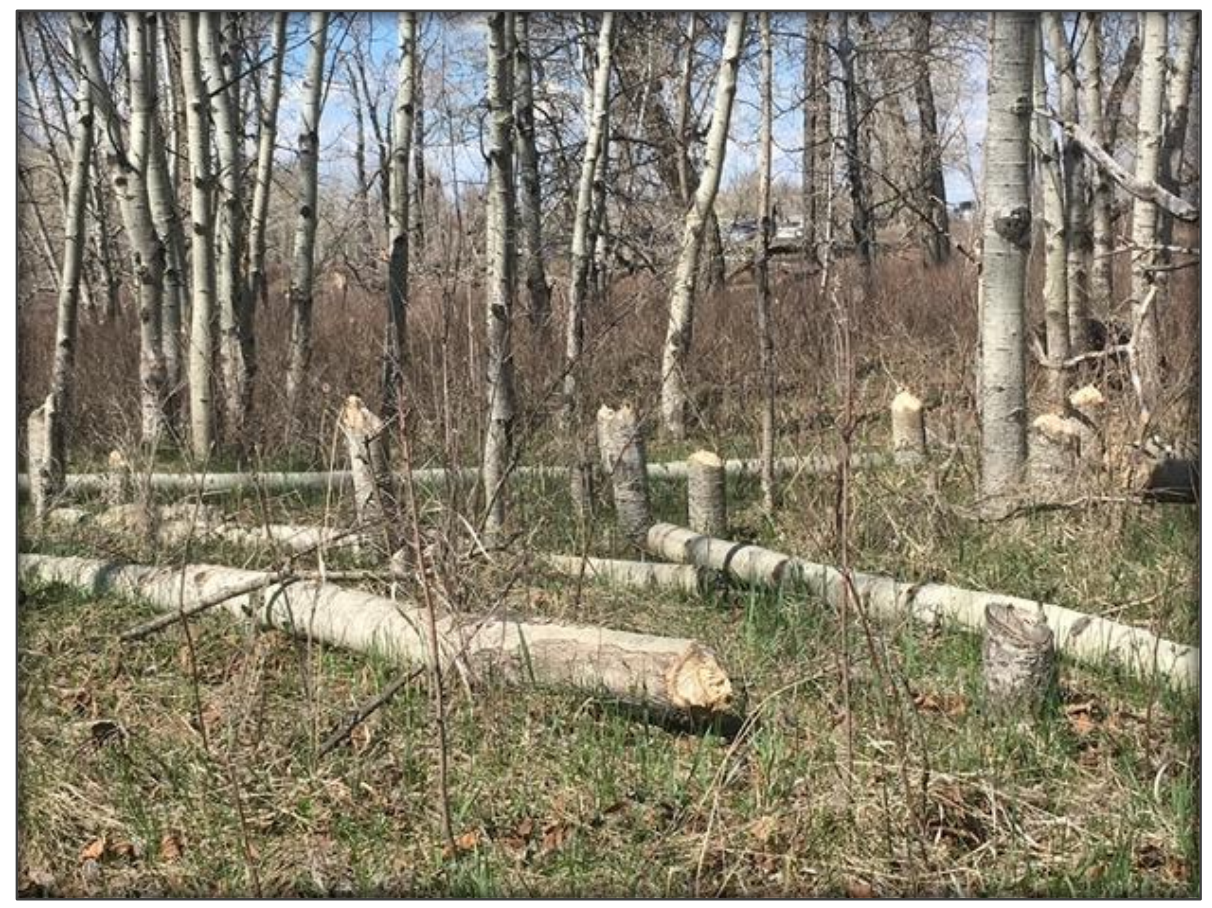

first time on the land jolted

my spirit I remembered

it is not awakening, it is coming home

a (re)awakening deep in my bones

hair in braids

I hopped and scampered

through the shady aspen grove

searching

for the right place, you know, the one where time slows

to match the rhythm of ancestral land and old stories

breath caught in the sun-filled clearing

where ksistaki the beaver

hard at work

chomped down aspen trees

shrunk them down

short, carved off stumps 
a visitor here, I sat

quietly adjusting to small offerings of time

reminding me

of earthly relatives

\section{Circle Teachings}

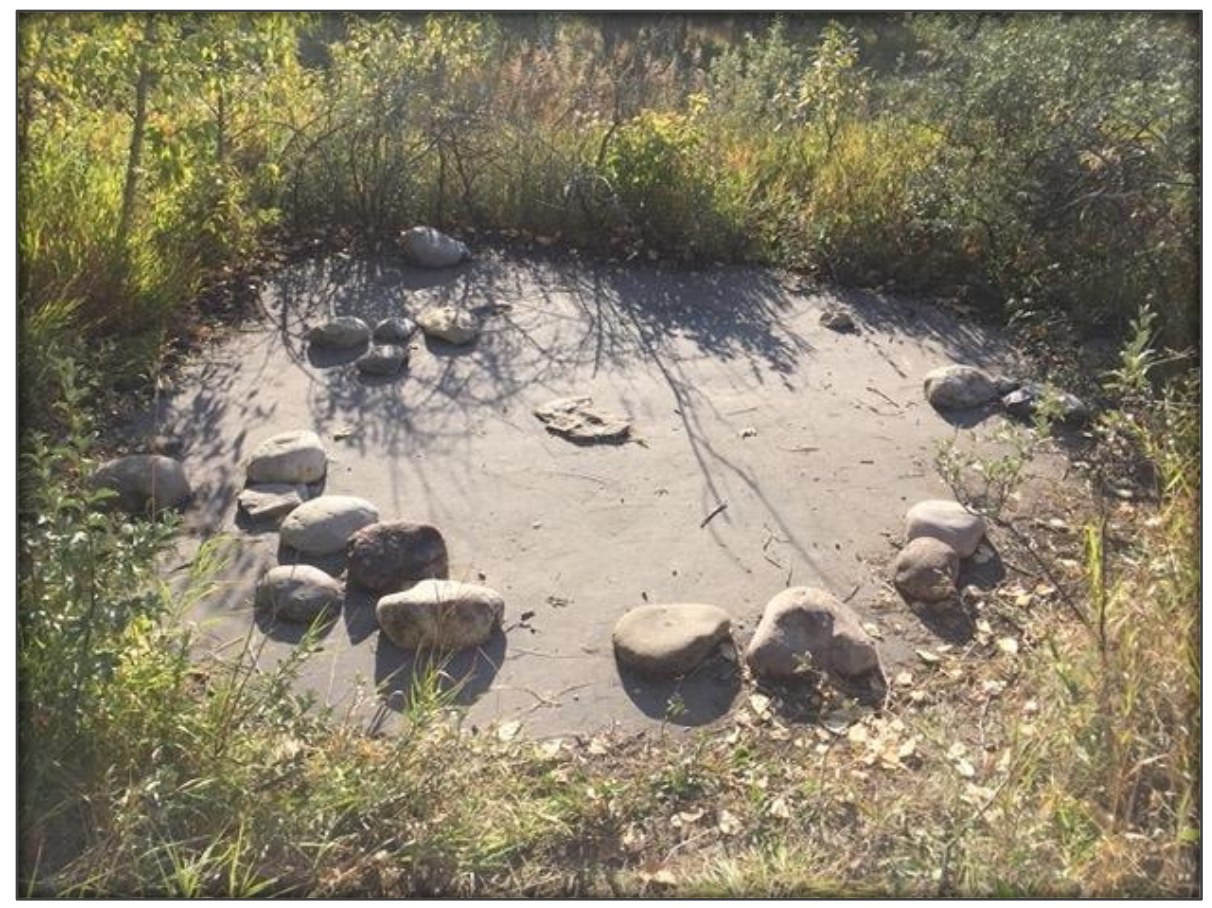

1.

It is all about circles, she told me when I was a tiny chickadee

beginning my journey

2.

the drum is a circle, beginning at the centre spiralling outward in a continuous circular motion of learning

3.

everything is in circles

we go to the left

beginning in the east with the sunrise

following the sun throughout the day

cycling through the seasons 
4.

we care for each other in the circle listen and speak from the heart trust that what we say stays safely here inside

Strawberries, Hearts, Gifts

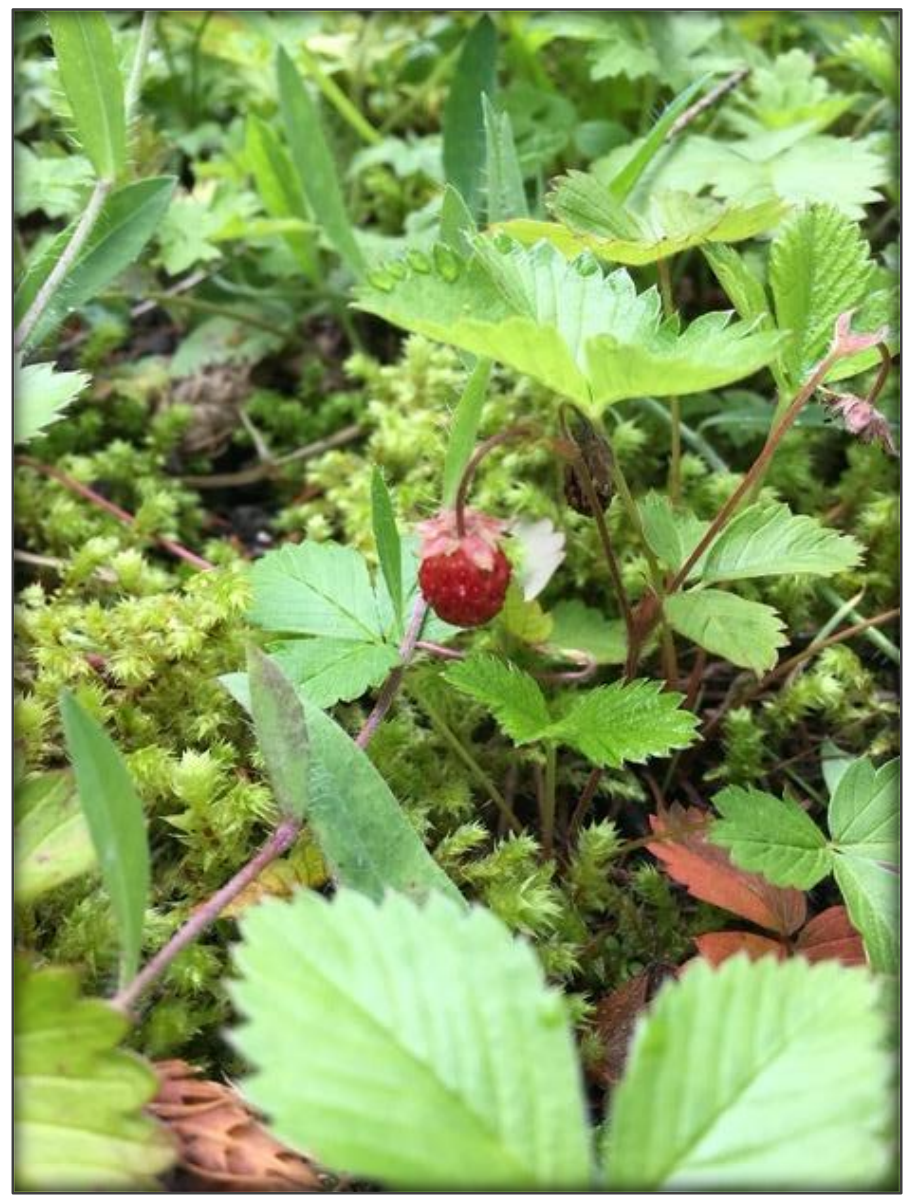

Did you know that the roundest, juiciest berries grew on the sunny slope up the hill in front of Uncle Ernie's cabin?

they used to

grow in the old driveway beside our log house when I was young until too many cars parked there the trees grew too tall 
and one year they didn't return

I knew the rhythm of these berries

felt it in my own bones

in early summer, right after school let out, white blossoms beckoned

if you missed the message, forgot to look we just found leaves and red runners reaching out new possibilities for next season

if you pinched too hard, they squished

all you could do was suck the juice from your fingers, and keep looking

leave the half ripe ones and come back tomorrow leave the ones with a nibble or a hole to share with the mice and ants

today, some grow over in the birch grove an offering for a few days in early summer

long before I learned from the ancestors that strawberries are gifts of reciprocity with the land and others

my heart understood the gift with each surprise burst offered in juicy red sweetness 
Ko'komikisum

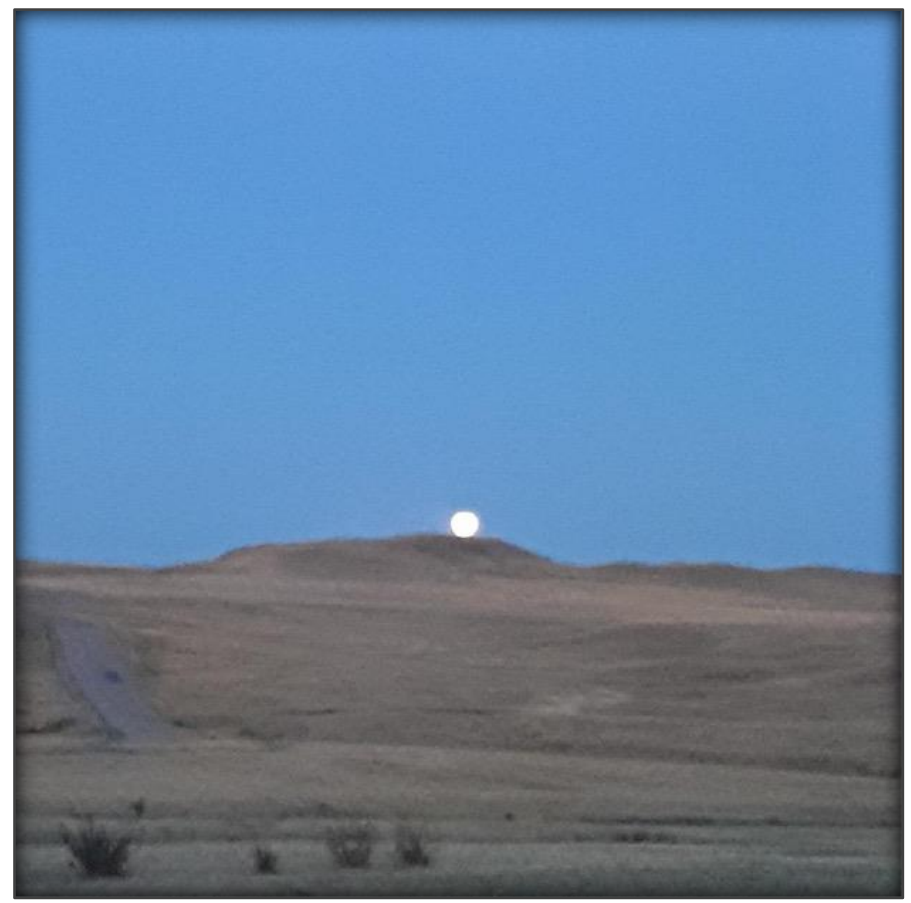

Sapphire sky white moon cradles

my dreams in its curved

palm an instant

before sunrise

time suspends, I am

breathless

while intense velvet

sapphire sky holds the secret

of how my day will unfold

magic fades leaving

a pink-purple ribbon

of wonder weaving

its way through

snowy mountain peaks

as the sky simultaneously

brightens and pales,

white moon gently

tosses my destiny down

to earth,

then

the smile reaches my eyes 


\section{(Re)Imagining Curricular Spaces}

The original purpose of this poetic photovoice inquiry began as a way to define my positionality. Through this work, I hoped to inspire other educators and researchers to do the same through experiences on the Land. The reflexive practice of photovoice evolved this intention to also evoke purpose and a counter-reaction to feeling burned out from the institution of school. When Elder Saa'kokoto and I visit with teachers out on the Land, their first comments are inevitably "I had forgotten what this feels like" or "I need to do this more often. I am too connected to my technology" or "I am too busy" or "I need to stop rushing". Inspired by the notion of (re)imagining curriculum, I am reminded of Elder Saa'kokoto's message about the importance of sharing these land-based stories, teachings and noticings around the kitchen table.

This was not a straightforward task of collecting photographs and writing up my thoughts. Poetry and Elder Saa'kokoto's teachings nudged me to write to discover what exactly moved me in each photo. I became part of the writing experience as evocative memories activated a sense of the familiar from my Western upbringing and also of new possibilities, inspired by Blackfoot ways of knowing, being and doing. It is important-but not enough as a settler-to love a place. I sought a critical understanding of a place. I listened for the language and stories that reside there, and the relationships with the more-than-human. This reciprocal love with the Earth and our more-thanhuman relatives provides a desperately needed path towards reconciling ways of knowing so that all humans can learn and practice stewardship of the Earth. As Robin Wall Kimmerer (2020) points out, we can only learn by placing Indigenous values and traditional knowledge at the centre of these conversations.

\section{(In)Conclusion}

Working together with poetry and engagement with these land-based pictures revealed that I am constantly searching. Searching for strawberries and kakhsin and sweetgrass and okonokii. Engaging in photovoice empowered me to look at my experiences in a different way. These poems and photos circled around, revealing the ever-present connections to patience, reciprocity, and love again and again. Like educational philosopher Maxine Greene (2001), "I am what I am not yet" (para. 1) - I am always becoming. As I spiral slowly over time through land-based teachings, scholarly readings and critical self-reflection, I am learning. Indigenous ways of knowing ask me to behave differently in the world. I continue to adjust and (re)imagine (Donald, 2016) my positionality as an unsettled settler within my work. I tread carefully, and listen to the voices of our Elders, natoosi, the berries, kokokomokisum, the Land and the grass rustling in the grove where ksisktaki and ipootaiks visit together. 


\section{About the Author}

Stephanie Bartlett is a PhD candidate at the Werklund School of Education, University of Calgary, where she is also an instructor. Emerging from her experiences in collaborative creativity in educational practice, her research focuses on education for reconciliation, ecological and Indigenous pedagogy, poetic inquiry and life writing.

\section{References}

Abram, D. (1996). The spell of the sensuous: Perception and language in a more-than-human world. Pantheon.

Adams, A. (Producer), \& St. John, M. (Director). (2006). Colonization road [Documentary film]. Canada: Decolonization Road Productions.

Archibald, J. (2008). An Indigenous storywork methodology. In J. G. Knowles \& A. L. Cole (Eds.), Handbook of the arts in qualitative research: Perspectives, methodologies, examples, and issues (pp. 371-384). Sage. https://doi.org/10.4135/9781452226545.n31

Basso, K. H. (1996). Wisdom sits in places: Landscape and language among the Western Apache. University of New Mexico Press.

Battiste, M. (2013). Decolonizing education: Nourishing the learning spirit. Purich.

Chilisa, B. (2012). Indigenous research methodologies. Sage.

Cook, K., \& Buck, G. (2010). Photovoice: A community-based socioscientific pedagogical tool. Science Scope, 33(7), 35.

Coulthard, G. (2014). Red skin, white masks. University of Minnesota Press. https://doi.org/10.5749/j.ctt9qh3cv

Cruikshank, J. (2005). Do glaciers listen? Local knowledge, colonial encounters, and social imagination. University of British Columbia Press.

Donald, D. (2016). From what does ethical relationality flow? An Indian Act in three artifacts. In J. Seidel \& D. W. Jardine (Eds.), The ecological heart of teaching: Radical tales of refuge and renewal for classrooms and communities (pp. 10-16). Peter Lang.

Friere, P. (1995). A pedagogy of hope: Reliving pedagogy of the oppressed. Continuum.

Hasebe-Ludt, E, Chambers, C., \& Leggo, C. (2009). Life writing and literary métissage as an ethos for our times. Peter Lang.

Iseke, J. (2011). Indigenous digital storytelling in video: Witnessing with Alma Desjarlais. Equity \& Excellence in Education, 44(3), 311-329. https://doi.org/10.1080/10665684.2011.591685

Kelly, V. (2018). Foreword: Walking in a good way with all our relations. In E. Hasebe-Ludt \& C. Leggo (Eds.), Canadian curriculum studies: A métissage of inspiration/imagination/interconnection (pp. xvi-xvii). Canadian Scholars.

Kovach, M. (2000). Creating indigenous research frameworks. In M. Kovach, Indigenous methodologies: Characteristics, conversations, and contexts (pp. 39-54). University of Toronto Press. 
Leggo, C. (2019). Research as poetic rumination: Twenty-six ways of listening to light. In R. Irwin, Hasebe-Ludt, \& A. Sinner (Eds.), Storying the world: The contributions of Carl Leggo on language and poetry. Routledge.

Little Bear, L. (2000). Jagged worldviews colliding. In M. Battiste (Ed.), Reclaiming indigenous voice and vision (pp. 77-85). University of British Columbia Press.

Marten, K., \& Mirraboopa, B. (2003) Ways of knowing, being and doing: A theoretical framework and methods for indigenous and indigenist research. Journal of Australian Studies, 27(76), 203-214. https://doi.org/10.1080/14443050309387838

Prendergast, M., Leggo,C., \& Sameshima, P. (2009). Poetic inquiry: Vibrant voices in the social sciences. Sense.

Regan, P. (2010). Unsettling the settler within: Indian residential schools, truth telling, and reconciliation in Canada. University of British Columbia Press. https://www.ubcpress.ca/asset/ 9215/1/9780774817776.pdf

Sameshima, P., Fidyk, A., James, K., \& Leggo, C. (2017). Poetic inquiry: Enchantments of place. Vernon. Simpson, L. (2017). As we have always done: Indigenous freedom through radical resistance. University of Minnesota Press.

Smith, A. (2019). Conquest: Sexual violence and American Indian genocide. South End Press.

Smith, L. T. (2012). Decolonizing methodologies: Research and Indigenous peoples (2 ${ }^{\text {nd }}$ ed.). Zedbooks.

Styres, S. (2019). Literacies of land: Decolonizing narratives, storying, and literature. In L. T. Smith, E. Tuck, \& K. W. Yang (Eds.), Indigenous and decolonizing studies in education: Mapping the long view (pp. 24-37). Routledge.

Tanaka, M. (2016). Learning \& teaching together: Weaving Indigenous ways of knowing into education. University of British Columbia Press.

Teachers College, University of Columbia. (2001, September 21). Flunking retirement: A chat with Maxine Greene. https://www.tc.columbia.edu/articles/2001/january/flunking-retirement-achat-with-maxine-greene/

Truth and Reconciliation Commission of Canada. (2015). Final report of the truth and reconciliation commission of Canada. Volume one: Summary. Honouring the truth, reconciling the future. James Lorimer.

Turner, N. J., \& Spalding, P. (2018). Learning from the earth, learning from each other: Ethnoecology, responsibility, and reciprocity. In M. Asch, J. Borrows, \& J. Tully (Eds.) Resurgence and reconciliation: Indigenous-settler relations and earth teachings (pp. 265-291). University of Toronto Press.

Tuck, E., \& Gaztambide-Fernández, R.A. (2013). Curriculum, replacement, and settler futurity. Journal of Curriculum Theorizing 29(1), 72-89. https://journal.jctonline.org/index.php/jct/article/view/411

Tuck, E., \& Yang, K. W. (2012). Decolonization is not a metaphor. Decolonization: Indigeneity, education \& society, 1(1), 1-40. https://jps.library.utoronto.ca/index.php/des/article /view/18630 
Tully, J. (2018). Reconciliation here on Earth. In M. Asch, J. Borrows, \& J. Tully (Eds.), Resurgence and reconciliation: Indigenous-settler relations and Earth teachings. University of Toronto Press.

Wall Kimmerer, R., \& Turner, N. (moderator). (2020, September 24). Braiding ways of knowing. In M. Richardson, D. Suzuki, \& D. Courchene, Jr. (Chairs), Reconciling ways of knowing. https://www.waysofknowingforum.ca/episode3

Wall Kimmerer, Robin. (2013). Braiding sweetgrass: Indigenous wisdom, scientific knowledge, and the teachings of plants. Milkweed.

Wang, C., \& Burris, M. (1997). Photovoice: Concept, methodology and use for participatory needs assessment. Health Education and Behaviour, 24, 369-387. https://doi.org/10.1177 /109019819702400309

Wilson, S. (2008). Research Indigenous research methods. Fernwood.

Wilson, S. (2007). Guest editorial: What is an indigenist research paradigm? Canadian Journal of Native Education, 30(2), 193-195. 